\title{
Laudacja w związku z odnowieniem doktoratów Profesor Katarzyny Sójki-Zielińskiej i Profesora Stanisława Salmonowicza
}

Magnificencjo, Panie Dziekanie, Dostojni Jubilaci, Szanowni Państwo!

Ponad 52 lata temu, 21 stycznia 1960 roku, na Wydziale Prawa Uniwersytetu Warszawskiego, w Gmachu Seminaryjnym (dzisiejszym Collegium Iuridicum I) w sali 37 (dzisiaj 209), odbyły się dwie obrony doktorskie: najpierw (o godz. 10) swą rozprawę (Fideikomisy familijne $w$ prawie pruskim XIX $i$ poczatku XX wieku) przedstawiła z sukcesem pod osąd Rady Wydziału mgr Katarzyna Sójka-Zielińska. Potem (o godz. 12) swojej dysertacji (Krystian Bogumit Steiner, 1746-1814, prawnik, historyk i literat polskiego Oświecenia) bronił z powodzeniem mgr Stanisław Salmonowicz. Promotorem obojga doktorantów był profesor Karol Koranyi, a referentami, jak wówczas mówiono, Witold Czachórski i Tadeusz Cieślak w przypadku Pani Profesor Sójki-Zielińskiej, oraz Michał Patkaniowski, Władysław Sobociński i Zbigniew Zdrójkowski w przypadku Pana Profesora Salmonowicza. Tak oto w styczniowy dzień (z przelotnymi opadami mokrego śniegu i temperaturą w okolicach zera, jeśli wierzyć relacjom Wicherka w ówczesnym „Życiu Warszawy"), splotły się na wiele dziesiątków lat losy dwojga adeptów nauki historycznoprawnej. Dzisiejsza uroczystość, wspólne odnowienie uzyskanych przed ponad półwieczem doktoratów, jest tego najlepszym wyrazem i dowodem. Ścieżki życiowe obojga Jubilatów są zarazem pełne rozmaitych wydarzeń i znaczeń, które znakomicie oddają trudny, ale i zmieniający się klimat czasów, w jakich przyszło im odbywać studia, przygotowywać rozprawy doktorskie, a potem kontynuować pracę naukową. To jednocześnie - jak w pigułce - wyrazisty obraz środowiska polskich historyków prawa. Dlatego dzisiejsze spotkanie jest także świętem tej właśnie społeczności. Będę próbował przedstawić to, co z punktu widzenia naukowych dokonań i życiowych losów, a także ich symboliki dla świata historyków prawa, łączy naszych Doktorów. O swojej przyjaźni opowiedzą zapewne sami. 
Oboje wywodzą się z rodzin inteligenckich, w których tradycja niepodległościowa była pieczołowicie kultywowana. Dla obojga to pochodzenie społeczne stanowiło poważne obciążenie w latach studiów, odbywanych w najgorszym okresie polskiego stalinizmu, czyli w pierwszej połowie lat pięćdziesiątych. Oboje ukończyli je jednak cum laude w tym samym 1954 roku: Pani Profesor na Wydziale Prawa Uniwersytetu Warszawskiego, na podstawie pracy magisterskiej, pisanej pod kierunkiem prof. Koranyiego, Pan Profesor na Wydziale Prawa Uniwersytetu Jagiellońskiego, na podstawie pracy magisterskiej, pisanej pod kierunkiem prof. Michała Patkaniowskiego, na temat sądownictwa w rewolucyjnej Francji. Spotkali się na seminarium prof. Koranyiego: Katarzyna Sójka-Zielińska wyłowiona z grona najlepszych studentów przez swego Mistrza, Stanisław Salmonowicz - skierowany w 1956 roku do Warszawy przez prof. Patkaniowskiego, bo w Krakowie nie było dla niego miejsca w Uniwersytecie Jagiellońskim. Seminarium profesora Koranyiego było miejscem, gdzie zdobywało się najwyższej próby umiejętności warsztatu historycznoprawnego. Po latach Pani Profesor Sójka-Zielińska tak wspominała te nadzwyczajne spotkania:

„Słynne privatissima, prowadzone [...] w piątkowe popołudnia w mieszkaniu profesorostwa Koranyich, najpierw przy ul. Filtrowej, a następnie przy Brzozowej na Starym Mieście, daleko odbiegały atmosferą od zwyczajnych uniwersyteckich zajęć. Przypominały raczej spotkania rodzinne, pełne ciepła, życzliwości, serdecznego zainteresowania obojga Gospodarzy naszymi prywatnymi radościami i troskami. Uczyliśmy się na nich nie tylko historii prawa, ale i życia”.

Z takiej to wyjątkowej szkoły wyszli nasi Jubilaci.

Początkowo szli równo: w tym samym dniu uzyskali stopień doktorski, w tym samym roku (1966), choć już na różnych uniwersytetach, zdobyli stopień doktora habilitowanego; Profesor Sójka-Zielińska na naszym Uniwersytecie na podstawie rozprawy o prawnych problemach podziału gruntów chłopskich w Galicji na tle austriackiego ustawodawstwa agrarnego, Profesor Salmonowicz na Uniwersytecie Jagiellońskim na podstawie monografii o kodyfikacjach karnych oświeconego absolutyzmu. Potem ich losy potoczyły się już odmiennymi drogami. Katarzyna Sójka-Zielińska, niezmiennie związana w Uniwersytetem Warszawskim, osiagała tutaj kolejne awanse naukowe i piastowała ważne dla środowiska akademickiego funkcje: prodziekana Wydziału Prawa, dyrektora Instytutu Historii Prawa, kierownika Katedry Powszechnej Historii Państwa i Prawa. Karierę Stanisława Salmonowicza (rozpoczętą na Uniwersytecie Jagiellońskim, a potem kontynuowaną na Uniwersytecie Mikołaja Kopernika, gdzie objął Katedrę Historii Państwa i Prawa Polskiego, a w 1969 roku powierzono mu funkcję prodziekana Wydziału), przerwało w 1970 roku oskarżenie (połączone z aresztowaniem) o wspieranie antypań- 
stwowej działalności. Oznaczało to pozbawienie pełnionych funkcji, a następnie (mimo umorzenia śledztwa w tej sprawie) utratę w 1971 roku stanowiska na UMK. Od 1972 roku, dzięki poparciu wielu ówcześnie wpływowych przedstawicieli środowiska akademickiego (m.in. Karola Górskiego i Gerarda Labudy) profesor Salmonowicz podją pracę badawczą w toruńskim Zakładzie Historii Pomorza i Krajów Bałtyckich w Instytucie Historii PAN. Zakładem tym potem przez wiele lat z powodzeniem kierował. Do pracy dydaktycznej na Uniwersytecie Mikołaja Kopernika profesor Salmonowicz powrócił dopiero w 1982 roku, obejmując kierownictwo Katedry Historii Prawa Niemieckiego w Polsce. Ale choć, jak widać, curricula zawodowe naszych Jubilatów różniły się znacznie, niezmienna pozostała wspólnota naukowych zainteresowań i sposób patrzenia na specyfikę i znaczenie dyscyplin historycznoprawnych.

Nie jest zapewne przypadkiem, iż dla Obojga Czcigodnych Jubilatów obszarem szczególnego zainteresowania stała się epoka Oświecenia, a zwłaszcza ruch kodyfikacyjny. Był to ważny czas, w którym prawo stało się jednym z najistotniejszych narzędzi przebudowy ówczesnych społeczeństw i ustrojów państwowych, a jednocześnie określenia autonomicznej pozycji jednostki ludzkiej, wyposażonej w niezbywalne, naturalne prawa. Ta relacja państwo obywatel, która w Wieku Świateł nabrała podstawowego, konstytucyjnego znaczenia, stała się dla naszych Jubilatów ważnym motywem przewodnim ich twórczości (także tej, która traktowała o późniejszych epokach). Pani Profesor Sójka-Zielińska zajęła się kodyfikacjami cywilnymi, Pan Profesor Salmonowicz - kodyfikacjami karnymi. Bez ich znakomitych monografii nie da się dzisiaj dobrze poznać i - co ważniejsze - zrozumieć całego złożonego procesu przygotowywania kodyfikacji, ich założeń filozoficznych, proponowanych rozwiązań instytucjonalnych, a wreszcie szczegółowych regulacji prawnych, zawartych w konkretnych kodeksach. Trafnie pisze w swej recenzji profesor Dorota Malec, że monografia profesora Stanisława Salmonowicza „mimo upływu lat stanowi aktualne, wręcz wzorcowe opracowanie tematu”. Tę ocenę można odnieść także do monografii Profesor Sójki-Zielińskiej (wydanej w 2009 roku w nowej, poszerzonej wersji), przywołując w tym miejscu opinię profesora Wojciecha Witkowskiego, wyrażoną w recenzji, że „do dziś pozostaje [ta monografia] niezastapioną lekturą dla każdego historyka prawa, jak i współczesnego cywilisty". Kontynuacją kodyfikacyjnych zainteresowań Pani Profesor stała się znakomita monografia poświęcona kodeksowi Napoleona zawierająca, jak pisze recenzent, profesor Adam Lityński, „treści pięknie wmontowane w epoki, które kodeks przeżywał, w zmiany w nauce i orzecznictwie sądowym".

Fascynacja Oświeceniem i jego bezpośrednim dorobkiem nie ograniczała się w przypadku naszych Jubilatów tylko do wątków kodyfikacyjnych. Wiele miejsca w dorobku Profesor Sójki-Zielińskiej zajęły kwestie kondycji jednostki w obliczu państwa, zwłaszcza w warunkach oświeconego absolutyzmu 
i jego programu troski o szczęście każdego obywatela. Ten temat jest obecny również w twórczości Profesora Salmonowicza, ale bardziej z perspektywy państwa rewolucyjnego. Sylwetki spod gilotyny to sugestywne szkice pokazujące dramatyczne zderzenie ideałów wolności z brutalną machiną jakobińskiej dyktatury. Ten wątek Profesor Salmonowicz będzie potem w wielu tekstach rozwijać w odniesieniu do czasów już nam bliższych (dość przypomnieć tu teksty dotyczące polskiego stalinizmu, np. Między strachem a manipulacja. Inteligencja polska wobec stalinizmu).

Ważne miejsce w dorobku Obojga Jubilatów zajmują dzieje prawa i ustroju państw ościennych: Prus (potem Rzeszy) i Austrii. Praca doktorska Katarzyny Sójki-Zielińskiej dotyczyła ustawodawstwa pruskiego, praca habilitacyjna nawiązywała do ustawodawstwa austriackiego, a Jej główne dzieło, dotyczące wielkich kodyfikacji, w sposób nieunikniony podejmuje problematykę myśli prawnej, ale także i kontekst ustrojowy Prus oraz Austrii. W wielu innych tekstach Profesor Sójki-Zielińskiej, zwłaszcza dotyczących praw jednostki w epoce Oświecenia, w sposób naturalny pojawiała się tematyka przede wszystkim austriackiego Oświecenia. Prusy stanowią z kolei przedmiot szczególnego zainteresowania Profesora Salmonowicza. Najlepszym tego dowodem są dwie znakomite książki: biografia Fryderyka Wielkiego, wydana w serii Ossolineum i kilkakrotnie wznawiana, oraz - także mająca już kilka wydań - monografia Prusy. Dzieje państwa i społeczeństwa. Nie sposób poznawać dzisiaj historii państwa pruskiego bez lektury tych dwóch książek.

Oboje Jubilaci sięgają często także do tematów XX-wiecznych. Wiele miejsca w dorobku Profesor Sójki-Zielińskiej zajmują prace poświęcone polskiej nauce prawa doby międzywojennej, a główny przedmiot zainteresowania Autorki stanowi tutaj kwestia tradycji i kontynuacji, ukazywanych poprzez losy konkretnych wybitnych przedstawicieli nauki prawa (jak studia nad dorobkiem Ernesta Tilla, Karola Lutostańskiego czy Karola Koranyiego). Profesor Salmonowicz należy z kolei do prekursorów badań nad dziejami Polskiego Państwa Podziemnego w okresie II wojny światowej. Ukoronowaniem tych badań stała się monografia ukazująca ustrojowe struktury oraz dorobek Polskiego Państwa Podziemnego czasów hitlerowskiej okupacji.

Oboje Jubilatów łączy również pasja popularyzatorska. Pitaval krakowski, którego współautorem (obok profesorów Waltosia i Szwaji) jest Profesor Salmonowicz, miał wiele wydań i do dzisiaj stanowi cenne źródło informacji o ciekawych sprawach kryminalnych dawnego Krakowa. Wiele tekstów Profesora dotyczących Torunia nie pozbawionych jest publicystycznego rysu, co czyni je atrakcyjnymi także dla czytelników, którzy nie są uformowanymi historykami prawa. Wymienię dla przykładu: Gadki toruńskie czyli zagadki weselne z przełomu XVII i XVIII wieku, czy Myśl Oświecenia w Toruniu. Znakomitym przykładem popularyzacji jest książka Profesor Sójki-Zielińskiej Drogi i bezdroża prawa. Ta niewielka objętościowo publikacja, podejmująca jednak 
zasadnicze problemy z dziejów prawa, podporządkowana jest $\mathrm{z}$ niebywałą konsekwencją celowi wskazanemu we wstępie: „Zrozumieć Europę widzianą oczyma historyka prawa - to poznać tradycje europejskiej kultury prawnej, odnajdywać wspólnotę jej korzeni i dróg wiodących do współczesności”. Jest też dobrym dowodem pisarskich talentów Autorki. Celnie tę umiejętność podsumowuje profesor Witkowski, przywołując w swej recenzji znaną wypowiedź Rabindranatha Tagore: „Spałem i śniłem, że życie jest przyjemnością. Obudziłem się i zobaczyłem, że jest obowiązkiem. Kiedy zacząłem działać dostrzegłem, że obowiązek jest przyjemnością”, i konkluduje tak: „Dla prof. Sójki-Zielińskiej »obowiązek pisarski« wynikający z talentów osobistych i szerokiej erudycji był i jest bez wątpienia przyjemnością". Także dla czytelnika, o czym świadczyć może wyznanie profesora Lityńskiego: „Cenię tę książkę za jej przystępność, piękne ujęcie powodujące, że czyta się ją z zapartym tchem" i dodaje na koniec: ,jako czytelnik chcę szczególnie podziękować Pani Profesor za tę piękną i jakże mądrą książeczkę".

Oboje Jubilaci wynieśli ze szkoły profesora Koranyiego wszechstronność zainteresowań badawczych, świetne operowanie metodą prawno-porównawczą oraz umiejętność syntetycznych ujęć. Zwraca na to uwagę w swej recenzji profesor Stanisław Grodziski:

„Od początku swej drogi naukowej Pani Katarzyna służyła Powszechnej historii państwa i prawa - przedmiotowi zakładającemu szerokie, porównawcze badanie zjawisk prawnych. Michał Sczaniecki, bezpośredni poprzednik Katarzyny Sójki-Zielińskiej na katedrze, nawiązując do tradycji Stanisława Estreichera, z powodzeniem stosował metodę syntezy porównawczej [...]. Pani Katarzyna metodę tę kontynuuje".

Umiejętność łączenia ujęcia analitycznego z syntetyczną perspektywą w mistrzowski sposób opanował Profesor Salmonowicz. Podkreśla to kilkakrotnie w swej recenzji profesor Zygfryd Rymaszewski, a jako przykład podaje rozprawę Profesora poświęconą dziejom wschodniopruskich kodyfikacji prowincjonalnych (XVII-XIX wiek). Ten obszerny tekst, pełen subtelnych prawniczych analiz, i pokazujący nadzwyczajną żywotność prawa chełmińskiego, kończy błyskotliwa, syntetyzująca konkluzja odnosząca się do siły świadomości prawnej jako zjawiska modyfikującego obowiązujące prawo. Profesor Rymaszewski pisze z podziwem: „To istny majstersztyk. Tę konkluzję winien znać każdy badający kodyfikacje i oceniający ich skutki prawne”.

Każdy z naszych Jubilatów, niezależnie od wszystkich osiagnięć, o których była mowa wyżej, ma swoje wyjątkowe dokonania, w których ujawnia w szczególny sposób swój osobisty temperament. W przypadku Pani Profesor Sójki-Zielińskiej jest to podręcznik Historia prawa, w przypadku Pana Profesora Salmonowicza - sztuka recenzowania prac innych autorów. Podręcznik 
Pani Profesor jest nie tylko wykładem dla studentów, lecz stanowi niezastąpioną syntezę dziejów prawa i kultury prawnej w Europie. Jest dziełem będącym, jak pisze profesor Lityński,

„doskonałym połączeniem własnych przemyśleń i studiów uczonego i doświadczonego dydaktyka, gdzie faktografia i rozważania problemowe znajdują się w doskonałej symbiozie, a zawiłości naukowe idą w parze z przystępnością wykładu".

Sztukę pisania recenzji Profesor Salmonowicz uprawia od początków swej naukowej kariery. Trafnie pisze profesor Rymaszewski: „tu nie ma on sobie równych”. Rzecz nie w ilości (choć ta jest imponująca - ponad 400 recenzji), ale w sposobie konstruowania i bogactwie tekstów recenzyjnych, w których umiejętność lapidarnego pokazania podstawowych tez oraz zalet $\mathrm{i}$ wad recenzowanej książki czy rozprawy doskonale łączy się z polemicznym temperamentem Profesora. Te recenzje są także świadectwem Jego ogromnej erudycji i imponującej szerokości zainteresowań. Dodajmy, że swoje bogate „recenzyjne" doświadczenia udostępnił innym w wydanej w 1998 roku książce $O$ rzemiośle recenzenta. Studia z warsztatu historyka.

Szanowni Państwo,

Znaczenie dzisiejszej uroczystości nie wynika jednak tylko z braterstwa historycznoprawnych dusz naszych Jubilatów. Odnowienie doktoratów Profesor Sójki-Zielińskiej i Profesora Salmonowicza pozostaje bowiem w związku z 60-leciem Instytutu Historii Prawa Uniwersytetu Warszawskiego, którego powstanie, dorobek i znaczenie świadczą o szczególnej pozycji warszawskiego środowiska historyków prawa. Dzisiejsza uroczystość stanowi dowód, że jego rola nie ograniczała się tylko do kształcenia własnych kadr, ale że spod promotorskiej ręki naszych wybitnych profesorów wychodzili stąd także doktorzy, którzy następnie w innych uczelniach rozwijali w znakomity sposób naukę historycznoprawną.

Profesor Sójka-Zielińska i Profesor Salmonowicz zajmują w świecie historyków prawa miejsce wyjątkowe. W konkluzji swej recenzji profesor Witkowski podkreśla, że Profesor Sójka-Zielińska jest „uczoną o renomie krajowej i zagranicznej, cieszącą się niezaprzeczalnym i zasłużonym autorytetem środowiska historycznoprawnego, ale też wybitną przedstawicielką polskich nauk prawnych". Profesor Danuta Janicka, prorektor Uniwersytetu Mikołaja Kopernika i - dodajmy - uczennica Profesora Salmonowicza, kończy zaś swą recenzję w sposób następujący:

„Najwyższe kwalifikacje naukowe Profesora i jego nieskazitelna postawa etyczna, zwłaszcza w epoce PRL-u oraz okresie stanu wojennego, pozwalają Mu cie- 
szyć się niekwestionowanym autorytetem wśród polskich historyków i historyków prawa".

Podczas uroczystej promocji doktorskiej, pół wieku temu, nasi Jubilaci złożyli ślubowanie doktorskie. Po przeszło 50 latach od tamtego wydarzenia można z całym przekonaniem stwierdzić, że rocie tego ślubowania, zobowiązującego Ich do postępowania non sordidi lucri causa, nec ad vanam captandam gloriam, sed quo magis veritas propagetur, pozostali do dzisiaj wierni. Nie tylko w działalności naukowej, ale w całym swym życiu.

W uznaniu dla tej postawy i mając na uwadze naukowy dorobek Obojga Jubilatów, Senat Uniwersytetu Warszawskiego dnia 14 grudnia 2011 roku podjął dwie uchwały: o odnowieniu doktoratu Profesor Katarzynie Sójce-Zielińskiej i Profesorowi Stanisławowi Salmonowiczowi. Chcemy w ten sposób, jako wspólnota warszawskiej uczelni, złożyć hołd i podziękowanie naszym wybitnym Doktorom, którzy - jak wymaga tego nasz Statut - całym swym postępowaniem wybitnie przyczynili się do osiągania celów, którym służy Uniwersytet.

Pani Profesor, Panie Profesorze - ad multos annos! 